\title{
Acknowledgments of Permissions
}

The editor of the Sewanee Review has granted permission to include in this critical study various sections which had been previously published in that journal.

Liveright Publishing Corporation has granted permission to use quotations as follows:

From Mosquitoes, by William Faulkner. Copyright 1955 by William Faulkner. Reprinted by permission of Liveright Publishing Corporation.

From Soldiers' Pay, by William Faulkner. Copyright 1954 by William Faulkner. Reprinted by permission of Liveright Publishing Corporation.

Random House has granted permission to use quotations as follows: From The Sound and the Fury, by William Faulkner. Copyright 1929 and renewed 1956 by William Faulkner. Reprinted by permission of Random House, Inc.

From As I Lay Dying, by William Faulkner. Copyright 1930 and renewed 1957 by William Faulkner. Reprinted by permission of Random House, Inc.

From Absalom, Absalom! by William Faulkner. Copyright 1936 by William Faulkner. Reprinted by permission of Random House, Inc.

From Sanctuary, by William Faulkner. Copyright 1931 and renewed 1958 by William Faulkner. Reprinted by permission of Random House, Inc. From "All the Dead Pilots" in Collected Stories of William Faulkner. Copyright 1931 and renewed 1959 by William Faulkner. Reprinted by permission of Random House, Inc.

From Sartoris, by William Faulkner. Copyright 1929 and renewed 1956 by William Faulkner. Reprinted by permission of Random House, Inc.

From Light in August, by William Faulkner. Copyright 1932 and renewed 1959 by William Faulkner. Reprinted by permission of Random House, Inc.

From Intruder in the Dust, by William Faulkner. Copyright 1948 by William Faulkner. Reprinted by permission of Random House, Inc.
From The Hamlet, by William Faulkner. Copyright 1940 by William Faulkner. Reprinted by permission of Random House, Inc.

From Requiem for a Nun, by William Faulkner. Copyright 1950, 1951 by William Faulkner. Reprinted by permission of Random House, Inc.

From The Mansion, by William Faulkner. (C) Copyright 1955, 1959 by William Faulkner. Reprinted by permission of Random House, Inc.

From The Town, by William Faulkner. (C) Copyright 1957 by William Faulkner. Reprinted by permission of Random House, Inc.

From Go Down, Moses, by William Faulkner. Copyright 1941 by William Faulkner. Reprinted by permission of Random House, Inc.

From Pylon, by William Faulkner. Copyright 1935 and renewed 1962 by William Faulkner. Reprinted by permission of Random House, Inc.

From A Fable, by William Faulkner. Copyright 1950, 1954 by William Faulkner. Reprinted by permission of Random House, Inc.

From The Wild Palms, by William Faulkner. Copyright 1939 by William Faulkner. Reprinted by permission of Random House, Inc.

From The Reivers, by William Faulkner.

(C) Copyright 1962 by William Faulkner.

Reprinted by permission of Random House, Inc.

Chatto and Windus, Ltd., has given permission for these quotations to appear in publications within the British Commonwealth. 